\title{
Empowerment of Batik Tulis Groups through the Association
}

\author{
${ }^{1}$ HALQI YUSRA, ${ }^{2 S U G I T O,}$ \\ 1,2Depatement of Non Formal Education, Universitas Negeri Yogyakarta, Jl. Colombo No. 1. \\ Yogyakarta, Indonesia \\ email: 'halqi.yusra2016@student.uny.ac.id; ${ }^{2}$ sugito@uny.ac.id.
}

\begin{abstract}
The Giriloyo Batik Tulis Association is confronted with a fundamental challenge: how to maintain and preserve the tradition of batik tulis while the technology-based batik business grows. This study uses a qualitative descriptive approach to describe the empowerment of batik tulis groups in the Giriloyo and several inhibiting and solutions to issues associated with empowerment of batik tulis groups. The findings show that roles of paguyuban in empowerment are facilitator; coordinator; relation; information; marketing; social control; mediators; evaluation; and innovator.ax The inhibiting factors are the weakness in the HR sector, generational crisis, facilities, empowerment patterns, management, and unequal vision. The solution to the problems being pursued by the association are training programs; managing potential resources within the community as employment opportunities for the younger generation, launching professional personnel in certain fields; sustainable empowerment; grouping tourism village administrators with batik associations; strentening association through deliberation (musyawarah) and consensus (mufakat)
\end{abstract}

Keywords: giriloyo batik tulis association, empowerment, batik

\section{Introduction}

Indonesia is a country rich with culture and traditions, as well as diverse forms of local wisdom, one of which is "batik." UNESCO designated Indonesian batik as a world heritage on October 2, 2009. Since the United Nations Educational, Scientific, and Cultural Organization, or UNESCO, declared batik as a Humanitarian Heritage for Oral and Non-Cultural Culture, it has been recognized as a world heritage (Masterpieces of the oral and the Intangible Heritage of Humanity). Batik techniques, symbolism, and culture are thought to be ingrained in Indonesian culture. Indeed, UNESCO assesses the Indonesian interpret batik from birth to death. Batik is also a representation of Indonesia's cultural diversity, as evidenced by a variety of motifs.

The UNESCO declaration rekindled the Indonesian people's pride in Nusantara batik. This batik euphoria will benefit the country's economic growth and prosperity. In this sense, batik is not simply an expression of traditional Indonesian culture; it is also the nation's intellectual property, which serves as a pillar of the national economy via the creative industry. The batik industry, particularly small businesses, employs many workers, makes use of local natural resources, and contributes to national cultural wealth, and hence needs attention in its development (Cahyo, Rizali \& Bahari, 2016).

During this euphoria, batik tulis (hand drawn by the batik pen or canting), faces a dilemma caused by technological developments such as the introduction of stamped and printed batik- which their price is cheaper and than the price of batik tulis. It makes market competition is unavoidable. This diminishes people's interest in learning how to draw batik.

This study was conducted at one of Yogyakarta's batik associations, the Giriloyo Batik tulis Community in Wukirsari Village, Imogiri District, Bantul Regency. Currently, the association comprises 12 batik groups. The formation of this association is a turning point in the resuscitation of Giriloyo batik artisans who faced bankruptcy in 2004.

Received: August 25, 2020, Revision: March 25, 2021, Accepted: June 13, 2021

Print ISSN: 0215-8175; Online ISSN: 2303-2499. DOI: https://doi.org/10.29313/mimbarv37i1.6581

Accredited Sinta 2 based on the decree No.10/E/KPT/2019 until 2024. Indexed by DOAJ, Sinta, Garuda, Crossreff, Dimensions 
One measure of the revival's success is the implementation of breaking the Indonesian Muri Record for the longest batik in the country, which stood at 1,200 meters in 2007. This community's successes did not stop there; one among them is the Giriloyo Batik Tulis Center in Wukirsari Village, Imogiri District, Bantul Regency, which has developed into a batik tourism village in Yogyakarta.

The Wukirsari Tourism Village is remarkable because it has retained the tradition of batik tulis for generations and has become a pioneer of batik tulis in Bantul Regency (Miswar, 2017). The success of the Wukirsari batik industrial center is seen in business activities that promote collaboration between groups, mutual cooperation, and healthy competition, and are more concerned with conserving culture and history than with maximizing economic benefit (Yulianti \& Widiyanto, 2015). In terms of industrial batik marketing, Batik Tulis Giriloyo is positioned in quadrant II, alongside the Kebon Indah and Wijirejo batik industries. While two competitors, Kauman Batik Industry and Laweyan, sit above it. In this situation, the price of batik is rather high for Giriloyo batik artisans, but the artisans place a higher emphasis on maintaining the quality of the originally batik tulis to ensure that consumers remain satisfied with the artisan's batik products (Arlita \& Muta'ali, 2014).

The realization in the realm of informal education serves as the foundation for proposing solutions in this regard. To carry out educational activities, the Javanese society has developed wisdom through social groups, specifically the association, which cannot be separated from empowerment. There are various steps involved in achieving empowerment. First, assist the community in resolving their issues. Second, do an independent analysis (research) of the issue independently (participatory). This activity is typically accomplished through brainstorming, group discussion, and regular meetings with community members. Third, establish the problem's priority scale, which entails sorting and selecting the most urgent issues to be resolved. Fourth, devise strategies for resolving issues. Fifth, take concrete steps to resolve any issues that arise. Sixth, analyzing the complete series and empowering process to ascertain its degree of success and failure. (Suhartin et al., 2005)
Empowerment activities have
frequently been conducted in the Giriloyo-Batik Tulis Community; a variety of organizations also supported these activities, including the Regional Government (PEMDA), Non-Governmental Organizations (NGOs), and various universities in Yogyakarta. Of course, not all the many empowerments are properly implemented. Because of a few empowerment concerns in the Giriloyo Batik Tulis Community, this research is structured as follows: (1) How is the empowerment of the batik group business in the Giriloyo Batik tulis Community proceeding? (2) What are the impediments to empowerment of the batik group business in the Giriloyo Batik Tulis ? (3) What is the solution to the impediments to empowerment of the batik group business in the Giriloyo-Batik Tulis Community?

Empowerment, which is derived from the concept that originated in Europe during the Middle Ages, grew in popularity until the late 1970s, 1980s, and early 1990s (Hasan \& Azis, 2018). The concept of empowerment then has an effect on the recent theories that have developed (Ife \& Tesoriero, 2016). When evaluated through the operationalization process, the concept of empowerment exhibits two basic tendencies: first, the primary tendency is for processes that confer or transfer some power, strength, or ability (power) on a community or individual to become more empowered. This process can also be complemented by efforts to accumulate material assets that will assist in the design of their independence through the organization; and second, secondary tendencies, namely those that emphasize stimulating, encouraging, or motivating individuals to develop the ability or empowerment to determine their own life choices through a dialogue process (Hariwoerjanto, 1987). Empowerment of the community is defined as an endeavor to assist the community in developing their own capabilities so that they are free and capable of solving problems and making decisions on their own (Sunartiningsih, 2004).

Empowerment is a term that refers to a pattern of people's ability to acquire skills, particularly vulnerable and weak groups, for these groups to be capable of meeting their basic needs, contributing to prosperity, and participating in the development process and decisions that affect them. As a process, empowerment is a series of activities aimed at enhancing the power or empowerment of 
vulnerable groups in society, such as persons experiencing poverty. The group is not merely an instrument for policy implementation; it also serves as a platform for rural community empowerment (Hadi, 2010).

As a goal, empowerment refers to the conditions or outcomes desired by the social change movement; specifically, people who are empowered, have the power or possess the knowledge and ability to achieve their physical, economic, and social needs, such as self-confidence, the ability to express aspirations, a source of income, participation in social activities, and independence in carrying out tasks. The definition of empowerment as a goal is often used as an indicator of the success of empowerment as a process (Suharto, 2018). The concept of empowerment in the discourse of community development is always associated with the concepts of independence, participation, networking, and justice. Fundamentally, empowerment focuses on the individual and social levels of strength (Hikmat, 2010).

The objectives of community empowerment include various improvement efforts: (1) Education improvement (Better Education); (2) improvement of accessibility, especially regarding accessibility with sources of information/innovation, sources of financing, providers of products and equipment, marketing institutions (Better Accessibility); (3) improvement of action (Better Action); (4) institutional improvement (Better Institution); (5) business improvement (Better Business); (6) improved income (Better Income); (7) Improvement of the environment (Better Environment); (8) better living; (9) community improvement (Better Community)(Suharto, 2009).

The function of change agents in empowerment is inextricably related to their participation in community discourse (Mardikanto \& Soebiato, 2015). In this discourse, the actors of change act as community workers or enablers (Adi, 2008). As a community worker or enabler, there are four roles and skills that a community worker must possess as community empowerment, namely (1) facilitative roles and skills. In the facilitative role, there are seven specific roles, namely (a) social animation; (b) mediation and negotiation; (c) support provider (support); (d) forming consensus (building consensus); (e) group facilitation; (f) utilization of resources; and ( $g$ ) organize (organizing). (2) education (educational roles and skills). Education has four roles, namely (a) raising public awareness (consciousness-raising); (b) conveying information (informing); (c) confronting (confronting); and (d) training (training). (3) representation (representational roles and skills). Representation has six roles, namely (a) seeking resources (obtaining resources); (b) advocacy; (c) using the media; (d) public relations; (e) networking; (f) sharing knowledge and experience. Meanwhile, (4) technical roles and skills have four roles, namely (a) conducting research; (b) using computers; (c) make written and verbal presentations (verbal and written presentations); (d) ability to manage and control finances (management and financial control). Training helps development and increases productivity (Nguyen, L., Murphy, K., \& Andrews, 2019). Because the leader's authority has a significant impact on his subordinates' mobility, one duty of a transformational leader in empowerment is to act as a mediator, providing appropriate information, opportunities, support, and resources (Amor, Vázquez \& Faíña, 2019).

\section{Research Methodology}

This research uses a qualitative descriptive research method (Creswell, 2015a). The Giriloyo Batik Tulis Community is in Wikirsari Village, Imogiri District, Bantul Regency. This research was conducted in the Giriloyo Batik Tulis Community. The resource persons comprise one primary informant and five supporting informants. Besides interviewing informants or resource persons, researchers examine the roles, functions, and responsibilities of the Giriloyo Batik Tulis Association in Wikirsari Village, Imogiri District, Bantul Regency.

The study collected data through observation, interviews, and documentation. This research applies triangulation, member examination, and auditing to measure or validate the reliability of qualitative research (Creswell, 2015b). The data analysis in this study is qualitative, with initial data management involving data organization, transcription of interviews and field notes, as well as exploration, coding and categorization of the data. 


\section{Results and Discussion}

\section{Girloyo Batik Tulis Association}

The Giriloyo Batik Tulis Association began its existence and organization following the 2006 earthquake. With the background of the economic depression at the time, Giriloyo residents who were already well-known for their expertise in creating batik tulis passed down from their forefathers compactly organized the Giriloyo Batik Tulis Association. The Giriloyo Batik Tulis Association comprises 12 groups: Sungging Pile, Sido Mukti, Bima Sakti, Sekar Kedhaton, Giri Indah, Batik Giriloyo, Berkah Lestari, Sri Kuncoro, Suka Maju, and Breech.

The association's vision and objective are to train community members to become professional batik artisans, to improve member and community economies, and to establish Giriloyo as a center for the study of batik tulis. On October 2, 2014, during the early stages of the community's awakening, with assistance from multiple NGOs and the government, and with enthusiasm and appreciation from many agencies, a record was set. Prior to becoming self-sufficient, batik craftsmen in Giriloyo deposited their raw batik with a batik master in the city of Yogyakarta because the Giriloyo community could not color their batik at the time, and the price of raw batik was extremely low, plus batik masters frequently manipulated the price. From this, the Giriloyo batik group became more compact and self-sufficient.

The Giriloyo village began learning to color their own batik with the assistance of an NGO, a community was formed; from this community, a group called the 12 was founded, as well as a gazebo to house and sell batik from the community, particularly groups of association members. On the other hand, the government has begun repairing and expanding road infrastructure, and various community empowerment programs are being held to boost the economy of the community nearby Wukirsari village, one of which is the Tourism Awareness Group (POKDARWIS), which has been growing since its inception.

\section{The Significant Role of the Association}

From the results of interviews with informants IM, EP, IR, WA, RW, GT, there are 9 themes about the association, namely (1) facilitator (2) coordinator; (3) relations;
(4) information; (5) marketing; (6) social control; (7) mediators; (8) evaluation; (9) innovator.

Facilitator

Association is a facilitator that assists its members in conducting batik and tourism-related activities (Ulum, 2016). The role of a facilitator is identical to that of educating tourists about the ins and outs of batik. The facilitator's role also applies to the internal community, specifically as a tool of empowering members and communities nearby the association. Every day, members of the Pangurus Paguyuban (management of association) provide tour guides and assistance to tourists interested in learning to make batik. Apart from selling batik, a portion of the members' revenue comes from here, specifically tourism.

\section{Coordinator}

The role of groups in society can be determined by the group's objectives; indirectly, the group's effectiveness can be determined (Danim, 2012). There are six roles of the association and one of them is coordinator (Arifin, 2015). Paguyuban is a family-run organization that brings together three hamlets: Karangkulon, Giriloyo, and Cengkehan, as well as 12 batik groups. Each group's association has its own structure, activities, and governance. However, in addition to joining the association, a memorandum \& article of association was founded to regulate balance and solidarity in the development of the batik company. Regulation and consensus in the form of AD/ART exemplify the Giriloyo Batik Tulis Community's organizational role.

Paguyuban is organizational function promotes collaboration over the commandcentralistic model (Al-Kurdi, 2020). It is expected that familial nuances are more prevalent within the group.

Relation

Relationships cannot be separated from the community's history, even if they were previously independent groups until a community was founded. As a result, economic progress requires relationships to lighten and facilitate a task. Apart from that, the relationship is inextricably linked to social capital, a critical component of the business. The Association is obligated to establish broad relationships to enhance human capital and business. 
Information

The association is a filter for information that comes from within or outside the association; the function of this role has a significant impact on internal social developments, such as transparency between members; and this function also supports notification to external associations, specifically for information related to promotion, the current situation and conditions. Meanwhile, the association's role as an internal information disseminator is to inform the group about the association's activities and programs, whether they involve collaboration with external parties or internal activities such as meetings, task division, socialization, and other official activities of the association.

\section{Marketing}

The association has its own gazebo for product marketing, which is jointly managed by the current batik groups. A picket system is used to manage it, and each organization must send an envoy to assist the community. Not only are sales conducted at gazebos and fairs, but they are also conducted online via internet applications. Additionally, the association collaborates with local governments by participating in a variety of activities and exhibitions to raise awareness of the association's existence and the goods made by the Giriloyo Batik Tulis Association.

\section{Social Control}

One of the Giriloyo Batik Tulis Association's advantages is gotong royong. The members are still dense with familial elements, and the community maintains alternate pickets for each group. As a result, the association does not have employees in a specific field, such as a professional office. However, the association put a greater emphasis on the gotong royong element as a means of social control, as each group is involved in work. Additionally, the association's social control role is to preserve the harmony of the groups assembled under the association's auspices. The memorandum $\&$ article of association contains rules and consensus as instruments for this purpose.

Mediator

In its routine, the association holds regular monthly deliberations. The deliberations not only discuss problems that occur in implementing activities, but also discuss progress and the balance of social life in the community. The association's principal focus is on collectivity, as incorporating numerous groups into a single forum is not easy. Internal problems such as social jealousy are things that must be avoided within the community. The problems that are resolved together are problems related to common interests in managing the organization.

\section{Evaluator}

Each month, they held the association evaluation via a meeting of the association's deliberation; during this meeting, topics will be brought to the surface for analysis. This evaluation process is typically informal and is guided by family values. The deliberation meeting was a large gathering that included all members of the association; various issues concerning the state of the community were discussed, as was program evaluation, whether it was an associationsponsored program or one in collaboration with agencies and institutions that provide moral and material assistance.

Innovator

The association's role as an innovator includes the establishment of an education system for human resource development, as well as the production and management of tourist villages. The Giriloyo Batik Tulis Association's use of technology is limited to product marketing; for batik production, the community decides to manufacture batik manually or without the use of a machine (printing) due to the nature of batik tulis.

\section{Inhibiting Factors in Business Development}

From the analysis of interview results, there are 6 inhibiting factors for business development, the descriptions are as follows:

\section{Human Resources Factor}

The Giriloyo Batik Tulis Association's present programs are hampered by a lack of specialists in management and information technology (IT). This is an unsolvable problem that has slowed the development of existing programs. A good deal of empowerment attempts has been made to address this issue but have not yet succeeded. Several program initiatives have been made in the areas of technology training, markets, tourism, and life skills coloring. However, this has not been fully implemented ideally due to the 
several interrelated factors that influence it, including limited ability to learn, which is affected in part by the board's average age and the presence of senior members.

\section{Regeneration Crisis Factor}

Uncertain salaries or income influences the younger generation to prefer employment with more guaranteed incomes that ensure welfare over batik, which takes a long time, and the selling price is perceived to be excessive compared to the work required and the results delivered. As a result, batik is less appealing to the younger generation and is only used as a hobby when they are not working or occupying their spare time.

\section{Infrastructure}

A website is one of the marketing tactics that enable economic actors to provide information about promoted products. Currently, the Giriloyo Batik Tulis Association does not have an official website; the information that circulates on the website or on the internet is still managed by individuals, as the association does not have an official one. This circumstance limits the association's ability to manage information effectively for marketing. Meanwhile, marketing inside the community is still done manually through gazebo sales and occasionally participation in various exhibitions.

\section{Empowerment Program}

Empowerment programs are frequently held, yet they are only one-time events with little sustainability. This condition becomes a complaint and has a negative impact on the communities; initially eager about developing their abilities, the communities grew less excited about participating in programs perceived to be transient or disposable. As a result, this is one of the reasons impeding the Giriloyo Batik Tulis Association's business development.

\section{Management}

The Giriloyo Batik Tulis Association itself has established memorandum \& article of association, but it has not been intensely implemented. This is partly because of the unfavorable organizational atmosphere in the association. Each group is given the capacity and authority to manage their internal affairs, including regulations and programs. The association only adjusts the aspirations brought by each group. Therefore, it is very necessary for human resources with integrity and group synergy in increasing the capacity of the community in managing existing resources and potentials, so that they can create new opportunities in their progress.

\section{Dissimilarity of vision}

Conflict management in Giriloyo Batik Tulis Association is based on the established family culture. The community's family culture reduces the incidence of internal problems that could undermine the stability and creative process of batik. As I am concerned, internal conflict's ripples are quite infrequent. If anything, it is really a matter of communication and administration. There are indicators of divergence of vision among the association's members, such as the problem of competency-based compensation.

Additionally, no significant internal conflict was discovered because of eyesight dissimilarity. This condition is a result of the collective ideals held by everyone and the family spirit that serves as the community's basis. However, prevention measures in the form of consensus are still required to avoid the creation of internal conflicts, which will have a significant impact on the development and operation of the association's activities.

The results confirm that the association has carried out its optimal role as a social group. Referring to the statement of (Soekanto, 2015), a social group is a collection or unity of humans who live together with a relationship between them. The relationship involves reciprocal relationships that influence each other and an awareness of mutual help. In society, not all of them can be categorized as social groups, while the conditions are as follows: (1) each member of the group must know he or she is part of the group concerned; (2) there is a reciprocal relationship between one member and another; (3) there is one factor that is shared by group members so that the relationship between them grows closer.

The Giriloyo Batik Tulis Association has fulfilled the requirements as a social group. It can be seen from the enthusiasm and collectivity of the members of the association in carrying out each of the association's agendas. This shows that the community has played an organizational role. The Giriloyo Batik Tulis Association has been operating for approximately 13 years, and it is not a short time. Solidarity is the main foundation that maintains the 
stability of the association. The relationship between the community members has been harmonious. Furthermore, the collective aspiration to preserve batik tulis becomes a bond of solidarity and forms their identity. The existence of a shared identity and regular interaction, according to (Suyomukti, 2014) is the character of a social group.

The results of the study found that there were 9 roles that were actualized by the association, including (1) facilitator; (2) coordinator; (3) relations; (4) information; (5) marketing; (6) social control; (7) mediators; (8) evaluation; and (9) innovator. A number of these roles have realized the vision and mission of the Giriloyo Batik Tulis Community as a center for batik studies and tourism.

According to (Adi, 2008), here are seven facilitative roles, namely (a) social animation; (b) mediation and negotiation; (c) support; (d) consensus building; (e) group facilitation; (f) utilization of resources; and (g) organizing. Meanwhile, the role of education has four derivatives, namely (a) raising public awareness (raising consciousness); (b) convey information (informing); (c) confronting; (d) training.

The association's facilitative role appears to result in internal empowerment, for example, by providing paguyuban members with access to marketing, exhibitions, and training. This stage can be seen as a means of growing and developing the community members' capacities and self-confidence in order to facilitate their independence and ability to solve problems (Suharto, 2018).

The educational goal is focused on transferring information about batik. To do this, community members are equipped with communication skills, as well as the ability to serve tourists and students. While other technological constraints can be solved, optimizing this sector is critical for the empowerment of batik group businesses. Business development is described as an endeavor to liberate a community from all constraints that impede its efforts to improve its wellbeing (Hasan \& Azis, 2018).

The lack of decent human resources can inhibit business development, so that this human resource factor is considered crucial. To address these issues, steps must be done, including the involvement of third parties or mediators who will intensely inspire, inspire, and motivate community members. In other words, continual assistance is provided to ensure that the empowerment program functions optimally and effectively. Sustainability and sustainable development can and should be a goal of developing living systems (Socio-ecological or complex adaptive systems) (Gibbons et al., 2020). As a result, a discussion attempt between the mediator and community members is a viable option, especially given the community members' advanced age (Hasan \& Azis, 2018).

Appropriate learning for the average age of community members must be approached precisely; else, it will be ineffective. Rather than fostering positive empowerment, it promotes apathy among community members. This is consistent with Prayitno's assertion that co-opting the knowledge system, legal system, political system, and ideology in the process of systematic empowerment will cause the birth of two distinct groups of people, the empowered community and the underprivileged community, which will eventually create a dichotomy between those in power and those who are controlled (Prayitno, 2013). As a result, it is critical to have the appropriate concept of empowerment that is compatible with the members of the community's sociocultural background.

The Giriloyo BatikTulis Association faces several hurdles in empowering batik group businesses, including the regeneration crisis. After investigation, it was determined that the root of the problem is insufficient financial fulfillment, particularly the business mentality founded on kinship, which has resulted in young people today being less pragmatic and materialistic. If the issue is welfare guarantees, the community's involvement as a social group is critical in collaborating with village elders, government officials, and young components to address these issues, as empowerment is generally a joint effort (Suharto, 2018).

Along with conserving the batik craft, youth involvement has the potential to result in innovative discoveries, which can boost business development initiatives. Additionally, today's business development strategy is aimed toward fostering the growth of as many technopreneurship-based enterprises as possible in order to create a dynamic and sustainable business degre. (Budiarto et al., 2018). 
By providing fascinating and up-todate features, the usage of new technology forces business actors to be creative. According to the author, the author does not believe that the procurement of website pages is important; rather, the author believes that the focus should be on the routine operation of website content. In this scenario, youth development is important. To meet the challenges posed by the new economic model, a collaboration between talent, tolerance, and technology is critical (Florida, Mellander \& Gulden, 2012).

Reflecting on the issues that frequently arise in the current digital world, MSMEs can be developed by enhancing the quality of several aspects, one of which is management (Budiarto et al., 2018). Additionally, strengthening the management sector is critical for avoiding the emergence of internal conflicts. While the gap in vision within the community is still small, if it is not accompanied by an effective management arrangement, it has the potential to hinder business development.

Thus, business development must be based on management that is oriented towards community empowerment, while the characteristics are: (1) Gradually, initiatives and decision-making processes to meet the needs of rural communities must be placed on the community itself; (2) The ability of the community to manage and mobilize resources that must be improved; (3) Paying attention to local variations; (4) Emphasizing social learning between the government bureaucracy and the community; (5) Forming a coherent network between the government bureaucracy and social institutions (Litaniawan \& Suasa, 2014).

Seeing the implementation of community development in the era of empowerment approach, it can be seen from the process and results. Empowerment should change community groups from marginal to empowered and developing, those who were originally the object of development become part of the subjects who participate in decision making. On the other hand, the government has also begun to reorient development policies. There are many things that affect the implementation of empowerment, one of which is the weakness of the concept or problems in implementing it (Soetomo, 2011).

\section{Conclusions}

There are several roles of paguyuban in empowerment which include: facilitator; coordinator; relation; information; marketing; social control; mediators; evaluation; and innovator. The inhibiting factors are the weakness in the HR sector, generational crisis, facilities, empowerment patterns, management, and unequal vision.

The solution to the problems being pursued by the association in empowering the batik group business from these types of obstacles is the human resource factor, namely through training programs; the regeneration crisis factor, namely by managing potential resources within the community as employment opportunities for the younger generation, so that there is awareness to preserve the culture of batik tulis; the facility factor is by launching professional personnel in certain fields; the pattern of empowerment is to seek sustainable empowerment; management is by grouping tourism village administrators with batik associations; the dissimilarity of vision is by deliberation (musyawarah) and consensus (mufakat). Of the 6 types of obstacles, it is the strengthening of the management sector that must receive special attention. If this sector can be optimized then other sectors, such as online promotion, regeneration, and so on will be overcome since management is the primary reference and foundation in empowering batik group business development.

\section{References}

Adi. (2008). Intervensi Komunitas Pengembangan Masyarakat Sebagai Upaya Pemberdayaan Masyarakat. PT Raja Grafindo Persada.

Al-Kurdi. (2020). The role of organizational climate in managing knowledge sharing among academics in higher education. International Journal of Information Management, 50, 217-227.

Amor, A. M., Vázquez, J. P. A., \& Faíña, J. A. (2019). Transformational leadership and work engagement: Exploring the mediating role of structural empowerment. European Management Journal.

Arifin. (2015). Dinamika Kelompok. CV. Pustaka Setia.

Arlita, M. N., \& Muta'ali, L. (2014). Analisis Strategi Pemasaran dalam Meningkatkan 
Daya Saing Industri Batik Tulis Giriloyo untuk Mendukung Pembangunan Wilayah di Desa Wukirsari, Imogiri, Bantul. Jurnal Bumi Indonesia, 3(3).

Budiarto, R., Putero, S. H., Suyatna, H., Astuti, P., Saptoadi, H., Ridwan, M. M., \& Susilo, B. (2018). Pengembangan UMKM Antara Konseptual dan Pengalaman Praktis. UGM PRESS.

Cahyo, A. N., Rizali, N., \& Bahari, N. (2016). Peran Teknologi Digital Dan Visual (Batik) Fraktal Dalam Perkembangan Batik Nusantara Dan Industri Kreatif. Brikolase, 8(2).

Creswell J. W. (2015a). Penelitian Kualitatif \& Desain Riset Memilih Di Antara Lima Pendekatan. Pustaka Pelajar.

Creswell J. W. (2015b). Riset Pendidikan, Perencanaan, Pelaksanaan, Dan Evaluasi Kualitatif \& Kuantitatif. Pustaka Pelajar.

Danim. (2012). Profesi Kependidikan. Alfabeta.

Florida, R., Mellander, C., \& Gulden, T. (2012). Global metropolis: assessing economic activity in urban centers based on nighttime satellite images. The Professional Geographer, 64(2), 178187.

Gibbons et al. (2020). The development, application, and refinement of a Regenerative Development Evaluation Tool and indicators. Ecological Indicators, 108105698.

Hadi. (2010). Konsep Pemberdayaan, Partisipasi dan Kelembagaan Dalam Pembangunan. Yayasan Agribisnis/Pusat Pengembangan Masyarakat Agrikarya (PPMA).

Hariwoerjanto. (1987). Metodologi dan Praktik Pekerjaan Sosial.

Hasan, M., \& Azis, M. (2018). Pembangunan Ekonomi \& Pemberdayaan Masyarakat: Strategi Pembangunan Manusia dalam Perspektif Ekonomi Lokal. Hikmat. (2010). Strategi Pemberdayaan Masyarakat. Humaniora Utama Press.

Ife, J., \& Tesoriero, F. (2016). Alternative Pengembangan Masyarakat Di Era Globalisasi Community Development. Pustaka Pelajar.
Litaniawan, F., \& Suasa, S. (2014). Kebijakan Program Nasional Pemberdayaan Masyarakat Mandiri Pedesaan pada Kecamatan Torue Kabupaten Parigi Moutong. Academica, 6(1).

Mardikanto, T., \& Soebianto, P. (2012). Pemberdayaan masyarakat dalam perspektif kebijakan publik. Alfabeta.

Miswar. (2017). Strategi Komunikasi Pemasaran Pokdarwis Wukirsari Dalam Meningkatkan Kunjungan Wisatawan Batik Tulis Giriloyo Desa Wisata Wukirsari Imogiri.

Nguyen, L., Murphy, K., \& Andrews, G. (2019). Cognitive and neural plasticity in old age: A systematic review of evidence from executive functions cognitive training. Ageing research reviews, 100912.

Prayitno. (2013). Kontekstualisasi Kearifan Lokal Dalam Pemberdayaan Masyarakat. Pusat Pengkajian, Pengolahan Data Dan Informasi (P3DI).

Suhartin et al. (2005). Model-Model Pemberdayaan Masyarakat. Pustaka Pesantren.

Suharto. (2009). Membangun Masyarakat Memberdayakan Masyarakat. PT Refika Aditama.

Suharto. (2018). Lembaga Komunitas Lokal (Studi Tentang Perannya Dalam Pemberdayaan Masyarakat Kelurahan Di Kota Semarang 2016). Sosio Dialektika, 2(2).

Soetomo. (2011). Pemberdayaan Masyarakat Mungkinkah Muncul Antitesisnya?. Yogyakarta: Pustaka Pelajar.

Sunartiningsih. (2004). Pemberdayaan Masyarakat Desa Melalui Institusi Lokal. Aditya Media.

Ulum. (2016). Perilaku Organisasi Menuju Orientasi Pemberdayaan. UB Press.

Yulianti, N. V., \& Widiyanto, D. (2015). Identifikasi Karakteristik Kluster pada Sentra Industri Batik Wijirejo dan Wukirsari Kabupaten Bantul. Jurnal Bumi Indonesia, 4(2). 